\title{
Pawn Execution to PT Pegadaian against Collateral Object Which Does Not Belong to the Pawner
}

\author{
Afdela Yunita; Busyra Azheri; Syofiarti \\ Faculty of Law, Andalas University, Padang, Indonesia
}

http://dx.doi.org/10.18415/ijmmu.v6i3.872

\begin{abstract}
The problems raised here include: the first is the procedure for binding collateral to PT Pegadaian (Persero) which object does not belong to the pawner. The second is about how the auction will be carried out at the execution of a pawn to PT Pegadaian (Persero) against a collateral object that does not belong to the pawner. The third is about how the legal protection against the owner of pawn collateral object in the implementation of an auction of pawn execution. This study applies an empirical juridical method with the nature of descriptive analysis. It utilizes primary data and secondary data. The results of the study showed that the provisions of Article 1152 of the Civil Code provide the possibility that the object pawned for collateral for debt do not have to be movable property of private property, but can also be movable property belonging to others. The procedure for binding collateral object that does not belong to the pawner is the same as binding the collateral object legally as evidenced by a Loan Proof Letter. Thus, everyone who comes to PT Pegadaian with the aim of borrowing money must carry collateral items by attaching a Personal Identity Card. The auction will continue when the pawner defaults on the agreement in accordance with the provisions in the Loan Proof Letter. Legal protection, for the auction of a pawn object, for the owner of a pawn collateral object is actually given by law; i.e. if it is proven that the pawnbroker receives a pawn in bad intention, the pawnbroker party is obliged to return the pawned obejct to the real owner. In the settlement of this case, the claim from the owner of the actual collateral object to PT Pegadaian was not granted because the real owner did not receive legal protection.
\end{abstract}

Keywords: Execution; Pawn; Collateral; Procedure; Pawnshop

\section{Introduction}

To fulfill daily needs, money is always needed to buy and pay for various needs. Sometimes, it becomes a problem because someone does not have the ability to meet those needs with the money that he/ she has. Thus, he/ she is then forced to borrow from various existing funding sources by using financial services. One of the financial services that provides credit facilities to the community by providing quick and simple credit at a small cost and does not require long bureaucracy is PT Pegadaian. ${ }^{1}$

\footnotetext{
${ }^{1}$ Santoso, Clairene EE. “Working Capital Turnover and Receivables Turnover: Its Influence on at PT Pegadaian's (PERSERO) Profitability". EMBA Journal: Journal of Economic, Management, Business and Accounting Research1.4 (2013).
} 
PT Pegadaian is one of the state-owned enterprises in Indonesia whose main activities are services that channel lending/ credit money to the community on the basis of pawn law with easy, safe and fast service procedures or can be called Fast and Safe Credit). ${ }^{2}$ PT Pegadaian is increasingly in demand by the community because its existence is really needed as a place for funding quickly and easily. ${ }^{3}$ Arrangements regarding the practice of pawn collateral are regulated specifically in the Civil Code in Book II of Chapter XX Article 1150-1160. Definition to the execution of pawn collateral is regulated in these Articles. The definition of pawn is regulated in Article 1150 of the Civil Code which states as follows:

"Pawn is a right obtained by a creditor on a movable property, which is handed over to him/ her by the debtor, or by his/ her power, as collateral for his/ her debt, and authorizes the creditor to repay the receivables from the item by overtaking other creditors with the exception of sales costs as the implementation of a decision on a claim regarding ownership or control and the cost of rescuing the item issued after the item is delivered as a pawn that must take precedence."

Pawn is a real agreement that also requires an agreement and is a real act in the case of delivering pawn objects to the creditor of pawnbroker. The procedure applied by pawnshops starts from the stage of submission, disbursement, and repayment of loans. When it is due and the customer has not repaid the loan, then the pawnshop gives another opportunity for the customer to extend the loan so that the collateral object is not auctioned off. PT Pegadaian always reminds customers by letter or telephone so that they immediately repay the loan before the due date.

For the sake of the validity of a pawn agreement, pawner must be an authority in controlling the collateral object. $\mathrm{He} /$ she also must have rights from the broker of the object to repayment. Collateral on pawn is material that guarantees creditors that the receivables must be paid. The right is called the retention right as explained in Article 575 paragraph (2) and 576 of the Civil Code that the retention right is the right to hold the property of the debtor so that the debtor fulfills his/ her obligations or pay the debt or carry out the engagement to the creditor. So, the retention right is basically an accessoir which means that it is attached to an obligation, achievement (debt) or commitment that must be paid or fulfilled by the debtor.

In a pawn agreement, there are several clauses which contain an agreement regarding the debt payable between the parties. ${ }^{4}$ In this case the party, who provides the pawn collateral, is referred to as a pawner (debtor), while the other party that receives the pawn collateral is referred to as a creditor. ${ }^{5}$ However, it does not rule out the possibility that with the agreement of the parties, the pawn object is held by a third party, as mentioned in Article 1152 of the Civil Code. Therefore, the third party is referred to as a third-party pawnbroker; it is also in the case of parties that guarantee the pawn collateral. If the debtor who gives the pawn is called the pawner debtor, if the collateral object is given by a third party, then he/ she is referred to as third-party pawner.

Provision of Article 1152 of the Civil Code provide the possibility that the object pawned for collateral for debt do not have to be movable property of private property, but can also be movable property belonging to others. In other words, a person can pawn their movable material to guarantee the debt of another person, or someone can have a debt guaranteed by using a moving object which belongs to someone else.

\footnotetext{
${ }^{2}$ Herfika, Cahyusha Desmutya. "Comparative Analysis of Credit Product Mechanisms in Conventional Pawnshop and Financing at Sharia Pawnshop". Student Scientific Journal FEB 2.1 (2013).

${ }^{3}$ Ulinuha, Ahmad. The Influence of Sharia Pawnshop Service and Image on Customer Decision in Using Pawn Services at Sharia Pawnshop of Majapahit Semarang Branch Office. Diss. IAIN Walisongo, 2010.

${ }^{4}$ Herfika, Cahyusha Desmutya. "Comparative Analysis of Credit Product Mechanisms in Conventional Pawnshop and Financing at Sharia Pawnshop". Student Scientific Journal FEB 2.1 (2013).

${ }^{5}$ Supriyadi, Ahmad. "Legal Structure of Rahn's Covenant in Kudus Sharia Pawnshop". Empirical: Islamic Research Journal 5.2 (2012).
} 
The principle of pawn collateral is that at the time pawner handed over the pawn of goods to PT Pegadaian, the power over the pawn object is transferred to PT Pegadaian party which is referred to the pawnbroker. ${ }^{6}$ Mastery of pawn object lasts until the customer (debtor) repays the debt. However, the right to control the collateral object does not include the right to use, enjoy or collect the products used as collateral.

Normatively, everyone who wants to enter into a pawn agreement must carry a movable object that belongs to the pawner (customer) itself and does not belong to someone else who is illegally obtained. The customer, in pawning the borrowed object to be pawned, must have permission of the real owner. When someone pawns other people's property that is borrowed without the permission of the actual owner, the owner of the actual object can make a claim to PT Pegadaian. This action should not be carried out by the owner of this collateral object.

\section{Statements of the Problems}

Based on the above description, the problems that can be raised are as follows:

1. How is the procedure for binding a collateral to PT Pegadaian which object does not belong to the pawner?

2. How is the execution of a pawn against a collateral object to PT Pegadaian which does not belong to the pawner?

3. How is the legal protection against the owner of a collateral object in the implementation of an auction of pawn execution?

\section{Research Method}

This study applies an empirical juridical method; i.e. an approach to existing legal regulations by looking at how the application or implementation in the field, whether or not is in accordance with applicable regulations. This study is descriptive analysis that describes precisely the circumstances, symptoms, characteristics of individuals or a particular group and find the existence of a relationship between a symptom and other symptoms in community. ${ }^{8}$

For this empirical legal research, the authors utilize data sources which include: (1) primary data; i.e. the data obtained directly by collecting a number of information through interviews with PT Pegadaian party. ${ }^{9}$ The interviewee was Mr. Syawaldi as the Operational Manager of PT Pegadaian (Persero) of Terandam Padang Branch Office and two customers who also pawned their movable property as collateral and (2) secondary data obtained through library research that utilized primary, secondary, and tertiary legal materials.

\section{Results and Discussion}

Binding Procedure for Collateral Object to PT Pegadaian (Persero) of Terandam Padang Branch Office Which Does Not Belong to the Pawner

The binding procedure must be carried out on goods received as collateral for credit which can be juridically/ legally accountable. This binding procedure is carried out in accordance with applicable legal

\footnotetext{
${ }^{6}$ Erangga, Adilla Sarah. "Pawn Operations with the Sharia System of PT Pegadaian (Persero) Surabaya". Accounting Journal of UNESA 2.1 (2013).

${ }^{7}$ Erangga, Adilla Sarah. "Pawn Operations with the Sharia System of PT Pegadaian (Persero) Surabaya". Accounting Journal of UNESA 2.1 (2013).

${ }^{8}$ Koesnoe, Mohammad. Basic and Positive Legal Methods. Airlangga University Press, 2010.

${ }^{9}$ Marzuki, Mahmud. Legal Research: Revised Edition. Prenada Media, 2017.
} 
provisions. This binding procedure can be made after the loan agreement is signed; considering that the loan agreement is the main agreement of the agreement on collateral objects or in other words the collateral agreement is an access to the principal agreement.

Based on the observations of researchers, the binding procedure for collateral at PT Pegadaian (Persero) is the same between the collateral object which belongs to the pawner and the collateral object which does not belong to the pawner (belongs to a third party). If the collateral object is authorized by the owner to a third party, the power of attorney must be attached. This form of pawn agreement is made in the form of a private written document as evidenced by a Loan Proof Letter. It is a letter which contains an agreement on accounts payable in which the form, content, and conditions are determined by PT Pegadaian (Persero) unilaterally. In this case, the customer only has to agree to the contents of the agreement and sign it.

This Loan Proof Letter is an important document made by PT Pegadaian which is a simple loan agreement deed in the form provided in advance by PT Pegadaian. One of the activities carried out by PT Pegadaiaan is the provision of loan that occurs when both parties have signed a Loan Proof Letter; i.e. between pawner (debtor) and the pawnbroker (PT. Pegadaian). If pawner has signed a Loan Proof Letter, this party (debtor) has agreed to the contents of the agreement set by PT Pegadaian. Thus, legal relations have occurred between pawner (debtor) and pawnbroker (PT Pegadaian) which will later lead to rights and obligations between the two parties.

In loan agreement that occurs between pawner (debtor) and pawnbroker (PT Pegadaiaan), Loan Proof Letter is evidence to obtain legal certainty and obtain the power of proof because the loan agreement with collateral is very important to maintain security and provide legal certainty for pawnbroker creditors to get certainty regarding the return of loans that have been given by pawnbroker to pawner in accordance with the provisions and time set and agreed upon at the time of signing the Loan Proof Letter. ${ }^{10}$

There is a problem that occurred at PT Pegadaian that the pawner apparently pawned object that did not belong to him/ her; but it is the object of another person which was borrowed without the permission of the real owner of the object. After the collateral object was auctioned since the pawner did not repay the obligation until the due date and also did not extend the repayment period, the owner of the object actually demanded PT Pegadaian which was not supposed to be carried out by the real owner because in this case PT Pegadaian always held the principle and referred to the provisions of Article 1977 paragraph (1) the Civil Code in accepting the collateral object which states as follows:

"Anyone who controls movable property not in the form of interest or receivables that do not have to be paid is considered to be the full owner."

So, based on the Article above, it is clear that anyone who comes to PT Pegadaian with movable property is considered the owner of the object.

The provisions of Article 1152 of the Civil Code also explain that the pawned objects do not have to be owned by debtors who borrow money. However, the object belonging to the debtor can also be pawned. Analysis of Article 1152 of the Civil Code states:

"Liens for tangible movable objects and receivables appear by submitting the pawn objects to the creditor or pawnbroker or what is returned by the creditor."

The liens are deleted if the pawn object is lost from the power of the pawnbroker. However, if the item is lost or taken from them, one has the right to claim it again.

According to Article 1977, the second paragraph, if the pawn objects have returned, the liens are never deemed lost. "In the absence of pawner's authority to act freely on the item, it cannot be accounted for by the creditor without reducing the right of the person who has lost the object to sue on it again."

${ }^{10}$ Dimyati, Khudzaifah and Kelik Wardiono. "Legal Research Methodology”. (2004). 
In the provisions of the Article, one may pawn the property of another person. Rights, to sue against pawning actions carried out by other parties who are not entitled to pawned object or for such actions, cannot be accountable to creditors. However, at the end of the provision, it is also emphasized that the existence of these actions that are carried out without rights, according to the provisions of Article 1152 of the Civil Code, do not reduce the right of the debtor to sue on it again. It is clear that Article 1152 of the Civil Code wants to emphasize that if someone claiming to be the owner of the pawned objects demands that the pawnbroker (creditor) returns the pawn which is not authorized to do the pawnshop, pawnbroker does not need to pay attention to it because PT Pegadaian is protected by law.

According to Assen/ Scholten, as quoted by Tan Thong Kie, the meaning of the article is clear that in the validity of pawning something, the authority of pawner is not a requirement. However, if the pawned object turns out to have been stolen from the owner, then the owner can claim again from the creditor without changing the price of the buyer (Article 582 and Article 1152 paragraph 4 of the Civil Code). If the pawned object is put into fraud by the debtor/ borrower of money, the owner cannot claim the object, without reducing his/ her right to sue the debtor for fraud.

Article 1152 of the Civil Code gives the possibility that objects pawned for collateral for debt do not have to be movable property; yet, it could also be the property of someone else. In other words, someone can pawn their movable property to guarantee the debt of another person, or someone can have a debt guaranteed by other people's property. If the debtor provides collateral him/herself then he/ she is called the pawner debtor and the party providing the collateral of another person is called the third party pawner. This provision can also be seen in Article 1150 of the Civil Code that pawn object can be submitter by people who are in direct debt or by someone else; this is what is called by third party pawner. Although, the party providing the pawn object basically must be the person who has the authority to carry out legal actions against the pawned movable object; on the contrary, the provisions of Article 1152 paragraph (4) of the Civil Code explain that even if the submission of the object is carried out by an unauthorized person, it does not result in the pawning agreement being legally flawed because it can be canceled or prosecuted based on Article 1131 of the Civil Code.

In this case, the real owner must demand the return to the person who borrowed the object as explained in Article 579 of the Civil Code "Each holder of a position in power who has bad intention has the following obligations:

1. In returning the object to the owner, he/ she must return all the results of the object even the results that are not actually enjoyed by him/ her, but which the owner is supposed to enjoy.

2. All costs incurred to save the object that has been in his/ her authority.

3. He/ she must replace all losses, costs and interest

4. If he/ she could no longer return the object, because perhaps the object had been lost beyond error or lost due to a catastrophe, he/ she must return it according to the price, unless he/ she could prove that the material would have to be destroyed if the owner has it."

What the owner can actually do with the leasing borrower is to demand the return of the borrowed object along with its costs, interest and losses. If the object has been received by the pawnbroker, the real owner has the right to receive compensation for recovering the object.

In connection with the above problems, based on Hans Kelsen's legal certainty theory, the legal regulations must be carried out by the parties in the loan agreement between pawner (debtor) and the pawnbroker (creditor). In this case, the Proof Letter Loan is an important document that is evidence to obtain legal certainty that has the power of proof. For creditors, it is proof of certainty regarding the repayment of loans by the debtor, while for the debtor it is evidence that he/ she has submitted movable object as collateral for a loan at PT Pegadaian. 
The main requirement that must be brought by every customer who wants to enter into a loan agreement is to bring the pawn object or collateral object along with the ID Card. In addition, there are other requirements that must be met which include providing a power of attorney from the owner of the object if it is being authorized, filling out the Claim Submission Form, signing a loan agreement, paying administrative fees and submitting the Vehicle Number/ Motor Vehicle Ownership Book for motorized vehicles.

Implementation of Pawn Execution to PT Pegadaian (Persero) against Collateral Object which Does Not Belong to the Pawner

This pawn execution is carried out if the debtor defaults because the object that is made as a collateral object is not redeemed until the specified period in the Proof Letter Loan. Therefore, PT Pegadaian must sell the collateral object through an auction. Prior to the auction, there were several related documents that must be submitted in the implementation of the collateral object auction sales system at PT Pegadaian. Documents that must be prepared consist of Collateral Object Submission List, Auction Sales List Report and Auction Report. These documents are very important to run a company. Then, the Object Handover Report is one of the important documents for delivering goods. This document should be signed when the procession is handed over from one company to another. Thus, if a dispute occurs, this report can be used as a proof of delivery of objects. All of these documents must be prepared before the auction begins which aims to record collateral object auction sales transactions. There are several benefits from these important documents:

1. Establish responsibility for the emergence of object auction sales transactions which means that each document is authorized by the relevant function as proof of liability for the use of authority for the execution of the transaction.

2. Record collateral object auction sales transaction data.

3. Reduce the possibility of errors by stating all events in written form.

4. Submitting basic information to other parties.

The obligation of pawner (debtor) is to pay the loan principal and interest in accordance with the provisions stated on the Proof Letter Loan. In the Proof Letter Loan, the loan start date and due date (repayment date) have been determined. In addition, the Proof Letter Loan also determines conditions, i.e. "If the loan die date is not repaid/ extended, the collateral object will be auctioned on the specified date in accordance with the provisions of Article 1155 of the Civil Code which explains that:

"If the pawner does not carry out obligations or defaults, pawnbroker has the right to sell the pawn collateral with the aim of taking repayments on the loan principal and the costs of selling the collateral."

The auction process sells the object for the public by offering prices that are increasing or decreasing in writing and/ or verbally to reach the highest price preceded by the sale of the default collateral object owned by pawner and carried out on auction in public.

Related to the auction procedure, PT Pegadaian has the authority to auction the collateral object directly on its own power (parate executie) without having to seek approval from the court. This auction is carried out through a public auction according to local customs and on the common conditions that apply if the pawner does not carry out his/her obligations to pay off the debt from the sale of the pawned object because the public auction is expected to get the highest price for the mortgage. From the results of the sale of the pawning object, the pawnbroker has the right to take the repayment of the debt as high as possible for the object pawned; the rest becomes the rights of the pawner (debtor). 
So, the problem that occurred at PT Pegadaian was due to the owner of the collateral object which actually demanded the pawnshop after the goods were executed without his/ her permission. This is unacceptable for PT Pegadaian since in this case, it is the borrower (pawner) that must be sued not PT Pegadaian (Persero) because Pegadaian is protected by law.

\section{Legal Protection against the Owner of the Collateral Object in Pawn Object Auction}

The object pawned by the pawner are sometimes problematic in terms of ownership because the position of pawner over rights as a bezitter/ ruler of the object is protected by law. Thus, pawnbroker does not question who has authority over the collateral objects; as long as the object is in the hands of the pawner (animus principle); ${ }^{5}$ i.e. the impression that someone who is in control is someone who has the object without questioning who the real owner is because the relationship to the object is indeed desired.

The problem arises when the pawner is an unauthorized person. So, it is not certain about who will be given protection for the pawned object whether it is the pawnbroker who has a good intention or the real owner who has full rights to the object.

In the Civil Code there are two indicators to determine who will be protected. The first indicator is good intention from the pawnbroker whether the pawnbroker has a good intention in authorizing the object. The second indicator is the principle contained in Article 1977 paragraph (1) of the Civil Code whose mastery must have the power as a legitimate title. The principle contained in Article 1977 of the Civil Code states that the indicators is considered the rightful owner of the object even though it is later proved otherwise. ${ }^{5}$

According to the provisions of article 1152 paragraph (4) of the Civil Code, it is stated that: "Pawner has no power to act freely with pawned object, it cannot be accounted for by the debtor who has received the item in a pawn procedure." The provisions of this Article determine exceptions to the principle of the person authorized to pawn the collateral object, stating that the pawnbroker cannot be held liable for the liens received from the pawner who is not authorized to pawn the item. ${ }^{6}$ Even though Article 1152 paragraph (4) of the Civil Code does not require that the pawnbroker must have good intention in the sense that the pawnbroker does not know whether the person who is authorized is the object or not, but generally the conditions are accepted. ${ }^{7}$

The consequence is when someone borrows by pawning the object, then the loan agreement is legal and the pawnbroker is protected by law as long as the pawnbroker has good intentions. Further consequences, the real owner cannot claim his/ her property with a revindication claim (the right to an object whose owner can claim wherever the object is).

\section{Revindication Claim for Borrowed Object}

According to Kartini Muljadi, the pawnbroker is protected from a lawsuit that may be submitted by the owner of the movable object to the pawnbroker in this case Burgerlijk Wetboek only determines that the real owner of the object can only claim its return if the object is lost or stolen. However, if the object has been lent by the real owner and the object is pawned by a borrower, then it is considered an error on the side of the real owner for lending the object to someone who cannot be trusted. So, the real owner must bear his/ her own risk.

In the Law of Prosecution, the return of a pawn object only occurs if the pawnbroker has a bad intention in terms of authorizing the object. Protection for the real owner does not occur if the pawnbroker has good intentions even though the good intention is not raised by the pawnbroker with careful action.

Therefore, legal protection for the real owner of a pawn collateral object, which is auctioned by the legal object, is if the pawnbroker is proven to receive the pawn in good intention. Thus, the pawnbroker (PT Pegadaian) is obliged to return the object that has been pawned to the real owner.

Regarding the problems that occurred at PT Pegadaian (Persero) of Terandam Padang Branch Office, there was no legal protection against the owner of the collateral object. In addition, the lawsuit 
from the owner of the collateral object cannot be granted because in this case PT Pegadaiaan is protected by law based on the provisions of Article 1977 paragraph (1) of the Civil Code and Article 1152 of the Civil Code. The real owner can only make lawsuit on the borrower/ user (pawner) to return the borrowed object along with costs, interest and losses as described in Article 579 of the Civil Code.

\section{Closing}

In the collateral binding procedure to PT Pegadaian (Persero) Terandam Branch Office which the object does not belong to the pawner, the binding procedure must be carried out on the object received as collateral object. This collateral binding procedure is a form of a pawn agreement in the form of a private written deed that is proven by a Proof Letter Loan. The pawning agreement occurs if the Proof Letter Loan has been signed by the pawner (debtor) and pawnbroker (PT Pegadaian). Every person who wants to make a loan agreement must bring the collateral object and show their ID Card. Related to the problem of the collateral object which does not belong to the pawner, in this case, PT Pegadaian has never questioned because it always refers to the principle of Article 1977 paragraph (1) of the Civil Code. In addition, the provisions of Article 1152 of the Civil Code also give the possibility that the pawned objects for loan collateral are not only movable property status of private property, but also movable property of other people.

The pawning auction execution against the collateral object occurs if the pawner (debtor) does not fulfill its obligation to return or extend the pawn period. PT Pegadaian (Persero) has the right to sell goods that become collateral objects through an auction. The auction conducted by PT Pegadaian is an exception to the implementation of procedures by the state auction office because PT Pegadaian has its own rights or power to carry out the auction without any interference from the state auction (parate executie). Before the auction is held, PT Pegadaian must inform the debtor who is defaulting in advance. Regarding the collateral object which does not belong to the pawner at PT Pegadaian (Persero) Terandam Padang Branch Office, the auction is carried out according to the procedure because in this case the pawner has defaulted on the provisions contained in the Proof Letter Loan.

Legal protection of the actual owner of the collateral object over the auction of a collateral object is granted by law if the pawnbroker is proven to have bad intention in receiving the pawn object. Therefore, the pawnbroker (PT Pegadaian) is obliged to return the pawned object to the real owner. However, if the pawnbroker has good intention in accepting the collateral object, then there is no legal protection against the real owner of the goods and he/ she cannot sue PT Pegadaian because in this case PT Pegadaian is protected by law.

\section{Suggestion}

PT Pegadaiaan (Persero) must be more careful and thorough in terms of accepting the collateral object provided by a pawner. Even though pawnbroker has good intentions, it still has to be realized through careful manner in accepting pawn objects. In addition, the community must also be more careful in lending something (goods) to people and must not trust someone who borrows something from us easily because this can harm the real owner of the object. PT Pegadaian must socialize or provide information to the public whose collateral object is auctioned because there are still many people who do not know and do not understand the auction itself. The owner of a collateral object who has good intentions should always get legal protection because in this case the owner of the collateral object does not want their object lost from their authority. 


\section{References}

\section{Books}

Dimyati, Khudzaifah and Kelik Wardiono. “Legal Research Methodology”. (2004).

Erangga, Adilla Sarah. "Pawn Operations with the Sharia System of PT Pegadaian (Persero) Surabaya". Accounting Journal of UNESA 2.1 (2013).

Herfika, Cahyusha Desmutya. "Comparative Analysis of Credit Product Mechanisms in Conventional Pawnshop and Financing at Sharia Pawnshop”. Student Scientific Journal FEB 2.1 (2013).

Herfika, Cahyusha Desmutya. "Comparative Analysis of Credit Product Mechanisms in Conventional Pawnshop and Financing at Sharia Pawnshop". Student Scientific Journal FEB 2.1 (2013).

Koesnoe, Mohammad. Basic and Positive Legal Methods. Airlangga University Press, 2010.

Marzuki, Mahmud. Legal Research: Revised Edition. Prenada Media, 2017.

Santoso, Clairene EE. "Working Capital Turnover and Receivables Turnover: Its Influence on at PT Pegadaian's (PERSERO) Profitability”. EMBA Journal: Journal of Economic, Management, Business and Accounting Research1.4 (2013).

Supriyadi, Ahmad. "Legal Structure of Rahn's Covenant in Kudus Sharia Pawnshop". Empirical: Islamic Research Journal 5.2 (2012).

Ulinuha, Ahmad. The Influence of Sharia Pawnshop Service and Image on Customer Decision in Using Pawn Services at Sharia Pawnshop of Majapahit Semarang Branch Office. Diss. IAIN Walisongo, 2010.

Legislation

1945 Constitution.

Government Regulation No. 51 of 2011 concerning Changes in the Form of Legal Entity from Public Company to Limited Company (Persero).

Law No. 19 of 2003 concerning State-Owned Enterprises.

Law No. 8 of 1999 concerning Consumer Protection.

R.Subekti dan R. Tjitrosudibio, Civil Code (Burgerlijk), $21^{\text {st }}$ Print, Pradnya Paramita, Jakarta, 1978.

Regulation of the Minister of Finance of the Republic of Indonesia No. 106 of 2013 concerning Implementation Guidelines for Auction.

Vendu Instructie (Auction Instruction of Staatsblad 1908 No. 190).

Vendu Reglement (Auction Regulation of Staatsblad 1908 No. 189).

\section{Copyrights}

Copyright for this article is retained by the author(s), with first publication rights granted to the journal. This is an open-access article distributed under the terms and conditions of the Creative Commons Attribution license (http://creativecommons.org/licenses/by/4.0/). 